\title{
Magyar helynevek olasz térképeken és útleírásokban
}

1. Bevezetés. Tanulmányom célja, hogy bemutassam, a magyar helynevek hogyan jelennek meg 20. és 21. századi olasz térképeken és útleírásokban. Arra is keresem a választ, hogy a történelmi események okán és az idő múlásával bekövetkezett változások, valamint a fordítói stratégiák aktuális divatja hogyan és milyen mértékben befolyásolta az olasz elnevezések ki-, illetve átalakulását. Miért van egyes városneveknek olasz megfelelőjük, míg másoknak nincs? Hogyan mondható, illetve mondható-e egyáltalán olaszul az, hogy Bácska vagy Lajtántúl? Munkám elsősorban korpuszelemzésre irányul, s nem célozza tágabb elméleti következtetések levonását.

A tanulmány első részében a vizsgált korpuszt, illetve a munkafolyamatot mutatom be, majd röviden rátérek a földrajzi nevek fordításának lehetséges müveleteire. Ezt követi a vizsgált névanyag elemzése, mely két szempont szerint történik (a különböző nyelvü változatok alkalmazása és a két ország topográfiai szemléletéből és igazgatási hagyományaiból adódó különbségek alapján), ezeken belül további (földrajzi) kategóriákra bontva az ekvivalenseket. A vizsgált földrajzi kategóriák: megyenevek, városnevek, tájnevek, domborzati nevek, víznevek. Végül pedig összefoglalom a kutatás eredményeit és a levont következtetéseket.

2. A vizsgált korpusz és a vizsgálat módja. Kutatásom 67, a Római Országgyülési Könyvtárban fellelhetö, a témába vágó kötet anyagára épül. E források mind 20 . vagy 21. századi, olasz kiadású és olasz szerzőjü térképek, atlaszok, útleírások, útikönyvek vagy történelemkönyvek. Érdekességképpen két korábbi (18. és 19. századi), illetve két magyar szerzőjü, de olasz kiadású könyvet is megvizsgáltam. A legtöbb forrás az 1930-as évekből származik, ami a korabeli nemzetközi kapcsolatok helyzetével, illetve az Olaszország és Magyarország közötti kölcsönös érdeklődéssel magyarázható. A térképek és az atlaszok szerzői természetesen földrajztudósok, míg az útleírásokéi utazók (pl. Noemi Ferrari de Nagy, Francesco Gemelli). Ez a helynévfajták szerinti kategorizáláskor fontos tényező, hiszen a földrajztudósok tisztában vannak a helynévfajták típusaival (hegység, dombság), az utazók azonban nem feltétlenül, így e tényező az elnevezések helyességét is befolyásolhatja.

A forrásokban előforduló helynevekből adatbázist készítettem. A munkám előzményeként szolgáló szakdolgozat ${ }^{1}$ függeléke egy olyan szótárszerü gyüjtemény, amelyben megtalálhatóak a magyar helynevek múltbéli és jelenlegi olasz megfelelői, mert - kétségtelen hasznossága ellenére - hasonló munka még nem készült.

3. A fordítói stratégiák. A helynévfordítás vagy éppen nem fordítás, azaz a magyar alak vagy a célnyelvi alak meghagyása gyakran vitát vált ki szakmai körökben is. Amenynyiben a fordítás mellett döntünk, a helynevek lefordítása, de már összességében a tulajdonnevek fordítása is komoly feladat a fordító számára. A nehézségek leküzdésére számos

\footnotetext{
${ }^{1}$ Itt szeretném megköszönni Fábián Zsuzsannának, hogy témavezetőmként segítségemre volt azonos címü, 2019-ben az ELTE BTK-n elkészített szakdolgozatom megírásában.
} 
fordítói stratégia létezik, ám ezek közül csak néhány használható a helynevek esetében. A továbbiakban csak ezekre a módszerekre térek ki, és mivel a fordítók különböző megoldásokat javasolnak a nehézségek megoldására, célszerü lehet több tipológiát ötvözni (CHESTERMAN 2000, KLAUDY 2012, VERMES 2005).

A) Átvitel. VERMES kifejezésével élve (2005) átvitel-nek nevezem azt a müveletet, amelyben az eredeti forrásnyelvi nevet egyszerüen, változatlan módon átültetjük a célnyelvbe. E logika alapján a magyar Duna olaszul szintén Duna lehetne. Ez a müvelet viszont nehézséget okozhat, amikor az adott szóban olyan betük/karakterek szerepelnek, amelyek nincsenek jelen a célnyelv ábécéjében, morfofonológiai rendszerében.

B) Behelyettesítés, transzformáció. KLAUDY szakszavaival élve (2012: 18) behelyettesitésnek vagy transzformáció-nak hívjuk azt a módszert, amikor a forrásnyelvben előforduló nevet egyszerüen behelyettesítjük a célnyelvben meglévő ekvivalenssel. Például a Duna olaszul Danubio. Ennek a módszernek a feltétele az, hogy létezzen az adott névre egy megfelelő a célnyelvben is.

C) Hiperonímia. E fordítási müvelet lényege, hogy az adott tulajdonnevet egy fölérendelt fogalommal (hiperonimával) helyettesítjük (1. pl. CHESTERMAN 2000: 102); például a Tisza egy olasz nyelvü müben a fiume ('folyó') nevet kapná. Nyilvánvaló, hogy ez a köznévi megoldás térképek és útikönyvek esetében nem használható, mert a puszta összefoglaló név használata félrevezető lenne.

D) Betoldás. Azt a folyamatot, amikor egy olyan köznevet toldunk hozzá a tulajdonnévhez, ami eredetileg nem szerepelt a forrásnyelvi formában, KLAUDY szavaival (2012: 101) magyarázó betoldás-nak nevezzük. Ennek célja az, hogy a célnyelvi olvasó számára is egyértelmü legyen, hogy egy folyóról, egy hegységről vagy egy városról van szó, ha egy számára ismeretlen földrajzi egység nevét olvassa. Így lenne olaszul il fiume Körös a mi Körös folyónk neve.

E) Szó szerinti fordítás. Ennek a stratégiának a lényege, hogy a tulajdonnévben szereplő közneveket lefordítjuk (1. CHESTERMAN 2000: 108). Például a magyar Velencei-tó olaszul: Lago di Velence. A tó szót helyettesítettük a célnyelvi megfelelőjével: lago.

4. A vizsgált névanyag elemzése. Vizsgálati eredményeimet két szempont szerint mutatom be: a különböző nyelvü változatok, illetve a két ország topográfiai szemléletéből és igazgatási hagyományaiból adódó különbségek alapján, és ezeken belül rendszerezem őket helynévfajták szerint.

4.1. Különböző nyelvű változatok alkalmazása. Az olasz célnyelvi szövegekben rendkívül gyakori volt a német alakok átvétele. Ennek történelmi okai vannak, hiszen Magyarország hosszú ideig a Habsburg Birodalom (később az Osztrák-Magyar Monarchia) része volt (mint Olaszország egyes területei is). Ezen felül valószínü, hogy a magyar helynevek németes alakjai terjedtek el az olasz irodalomban, hiszen a szerzők hosszabb ideig döntően német nyelvü forrásokból dolgoztak. Mindezek - mint a későbbiekben látni fogjuk - hatással voltak az elnevezésekre.

4.1.1. Városnevek. Fővárosunk nevének tanulmányozásakor a Buda-Pest (Imperato 1914: 7), Budapest (Tagliavini 1940: 11) és Ofen-Pest (Boroli-Boroli 1965: 282) alakokkal találkoztam. Ez utóbbi mü 1965-ben született, a térképrészlet viszont Európát ábrázolja 1748-ban. Mivel II. József 1784-ben tette hivatalos nyelvvé a németet a Magyar Királyság 
területén, ezért ebben az esetben nem magyarázható konkrét történelmi aktualitásokkal az a tény, hogy a magyar Buda név a német Ofen névvel cserélödik ki.

Győr városának esetében az újabb kiadású könyvekben fordult elö a magyar Győr név átvitele (Bardini 1961: 15, Tamborini 1990: 5), míg a német Raab név inkább régebbi kiadású müvekben szerepel (Leoni 1913: 27, Bucchi-Simeoni 1931: 61, Pullè 1934: 385, De Carlo - Molinelli 1941: 199). A német nevet használó források mindegyike vagy a Monarchia korából származik, vagy azt a korszakot dolgozza fel, vagy akkorra nyúlik vissza, amikor Magyarország a Habsburg Birodalom vagy az Osztrák-Magyar Monarchia részét képezte, így mind a 15 esetben, ahol előfordul, helyes és következetes a használata a szerzők részéről. De nemcsak a magyar és német, hanem az olasz és a latin formák is elöfordulnak a müvekben, bár jelentősen ritkábban: az olasz Giavarino hatszor (De Magistris 1917: 36-37), a latin Arrabona négyszer (Pullè 1934: 394, D’Alto 1989: 61). Érdemes megfigyelni a nevek etimológiáját: a város nevének első előfordulása (in civitate Jauryona 'Győr városában') a középkorra nyúlik vissza, és valószínüleg kapcsolatban áll a Jeur Geur személynévvel. A latin Arrabona név pedig a Rába Arrabo nevéből származtatható. Ebből alakult ki a Raab folyónév a németben, amelyböl metonímia útján megszületett a német Raab név Györ városára (FNESz.).

Kolozsvár nevét vizsgálva a magyar Kolozsvár (Mattei 1913: 167), a román Cluj (Migliorini 1933: 66) és a német Klausenburg (Brote 1896: 90) név átvitelével találkoztam, illetve a német név olaszos Clausenburgo változatával (Mattei 1913: 74). A leggyakoribb forma 16 előfordulással a magyar név, ezt követi 5-5 elöfordulással a román és német nevek átvitele. Az olaszos változat megjelenése szintén magyarázható az erdélyi nagyváros történelmi fontosságával, illetve ezzel párhuzamosan az olaszok gyakori és nagy létszámú erdélyi jelenlétével. Az 1974-től adatolható román Cluj-Napoca név az általam vizsgált forrásokban először 2006-ban jelenik meg, Kolozsvár (Cluj-Napoca) (Biagini 2006: 85).

A Pécs városnév vizsgálatakor is elöfordult az olasz Cinquechiese (De Magistris 1917: 39) és a német Fünfkirchen (Baratta 1954: 12, Touring 1991: 116-117), illetve a magyar név átvitele is (Tamborini 1990: 5). Ennek a városnak az esetében a szerzök következetesen használják a német megfelelöt, mindegyik forrás vagy a Monarchia idejére nyúlik vissza (Leoni 1913: 27), vagy ha későbbi, akkor a Monarchia korát ábrázoló térképszelvényen jelenik meg (Touring 1991: 116-117). Az olasz és a német megfelelő is ugyanannak a latin Quinque ecclesiae ('öt templom') elnevezésnek a megfelelője, amely a Pécsen eltemetett öt keresztény mártírra utal vissza (FNESz.).

A Szeged városnév esetében 13 alkalommal találkoztam a magyar név átvitelével, 18 alkalommal az olasz megfelelö (Seghedino) használatával, és 7 esetben a németesített Szeg(h)edin formával; ez utóbbi tehát a legritkább, arányaiban mégis viszonylag sokszor fordul elö. Csak két olyan forrásban található meg, amelyek a Monarchia idejére nyúlnak vissza (Leoni 1913, Hoduig 1915: 71-72); az összes többi mü, amely ezt az alakot használja, későbbi (Tamaro 1923: 130, Scrimali 1934: 57, Pullè 1934: 385). Viszonylag kevés az olyan magyar városnév, amelynek van olasz megfelelője, de a Szeged esetében, mint láttuk, létezik és használatos is a Seghedino név. Valószínüleg azért, mert a város már a Római Birodalom virágzása idején fontos kereskedelmi csomópont volt Dácia és Pannónia provinciák között. A névalak kialakulásához hozzájárulhatott a város hazai latin megnevezése is.

A Székesfehérvár városnév vizsgálatakor is előfordultak a magyar mellett (Tamborini 1990: 9), a német Stuhlweissenburg (Pullè 1934: 386) és a latin Alba Regia (Migliorini 
1933: 142) nevek átvitelei, illetve az olasz Alba Reale megfelelő behelyettesítése (Gemelli Careri 1728: 39). Az a tény, hogy ennek a városnévnek több idegen nyelvben vannak megfelelői, a város fontos történelmi szerepével magyarázható: a középkorban Székesfehérvár volt a királyi család szakrális központja, illetve a koronázás helyszíne. A magyar Fehérvár, Székesfehérvár név arra utal, hogy a királyi palota fehér kőböl épült, ami a nagyságot és az eleganciát szimbolizálja (FNESz.). Erre a városnévre is jellemző, hogy egyes szerzők ugyanazon müvében többféleképpen szerepel, például Giorgio Pullè könyvében szinte az összes fent felsorolt név megjelenik (néhol helytelenül írva): 1. Stuhlweissenburg; 2. Albareale (Székesfehérvár); 3. Székesfehéryvar, Stuhlweissenburg per i Ted., l'Alba Regia del Medio Evo [sic!] (Pullè 1934: 386, 403, 411). Ahogy láthatjuk, mind a három esetben más a fóváltozat: először a német alak önállóan, aztán az olasz alak kiegészítve a magyar névvel, végül pedig a magyar alak kiegészítve a német, illetve az olasz névvel. Elio Migliorini müvében ugyanez figyelhetö meg: 1. Alba Regia (Székesfehérvár); 2. Székesfeférvár (ted. Stuhlweissenburg) [sic!] (Migliorini 1933: 142, 171). A föváltozat egyszer az olasz, kiegészítve a magyar névvel, egyszer pedig a magyar név, kiegészítve a német alakkal.

4.1.2. Tájnevek. A vizsgált forrásokban Bácska esetében egyszer fordult elő német alak: Batschka (Pullè 1934: 403). Részben érthető, hogy nem sokkal a Monarchia szétszakadása után még a németes alakot használja a szerző a német betelepülők által sürün lakott terület megnevezésére. Ugyanakkor a többi forrásban már a szláv(os) Bačka ekvivalens áll, hiszen ez a terület Trianon után a Szerb-Horvát-Szlovén Királyság része lett (Ferrario 1933: 293, Migliorini 1933: 64, Balla 1937: 138-139, Visintin 1947: 137, Nangeroni 1950: 65-66).

A Lajtántúl esetében is előfordul a német-latin Transleithania (Imperato 1914: 7), de ennek írásváltozata, a Transleitania sokkal gyakoribb, és 1917-től már csak ez jelenik meg az olasz forrásokban. (De Magistris 1917: 96, Migliorini 1933: 5, Fornaro 2006: 8). (A Lajta folyónév etimológiájára és különböző írásmódjaira a 4.1.3. pontban még röviden visszatérek.)

4.1.3. Víznevek. A Balaton esetében, ahogy már fentebb említettem, szintén megtalálható a németes alak, olasz közszóval kiegészítve: Lago Platten. Egy forrásban találtam meg önállóan (Pullè 1934: 386), egy másikban pedig zárójelben a magyar alak mögött: il Balaton (ted. Plattensee) (Migliorini 1933: 52). Ezekben az esetekben is kérdéses, helyes-e a németes alakot használni; ugyanakkor az általam vizsgált müvekben a leggyakrabban (hússzor) előforduló fordítói megoldás a Balaton átvitele volt.

A Fertő esetében már kissé bonyolultabb a helyzet, hiszen ez a tó immár részben Magyarországon, részben Ausztriában terül el, ezért az itt előforduló, olasz földrajzi köznévvel kiegészített németes alakok kétségkívül indokoltak: lago di Neusiedel (Visintin 1947: 138), lago di Neusiedl (Pullè 1934: 387), lago di Neusiedlersee (Molfese 1989: 265). Megfigyelhető, hogy bizonyos szerzők többféle elnevezést használnak egyazon munkájukban, ami félrevezető lehet az olvasó számára: Fertö-tó (lago di Fertö), lago di Neusiedlersee, il lago Fertő (Molfese 1989: 265, 271).

A már említett Lajta folyónév vizsgálatakor is többféle megfelelővel találkoztam: a magyar folyónevet tartalmazó, olasz földrajzi köznévvel kiegészített il fiume Lajta mindössze egy forrásban lelhető fel (Cucchetti 1939: 15), míg a német-magyar vegyes alak: Lejta (Bucchi-Simeoni 1931: 54) és a németes alakok: Leita (Bucchi-Simeoni 1931: 59, 
Migliorini 1933: 27) és Leitha (Pullè 1934: 393, Tagliavini 1940: 25, Visintin 1956: 36) sokkal gyakoribbak.

A Dráva folyó esetében a létező olasz Drava ekvivalens fordul elő a leggyakrabban (hatszor), míg a magyar Dráva és a német Drau megfelelö is csak egyszer-egyszer. A német szót is tartalmazó megoldás (Drau/Drava; Leoni 1913: 27) Leonida Leoni 1913-ban kiadott müvében szerepel, ezért feltételezem, hogy a németes névhasználat oka az, hogy Dél-Tirol, ahol a Dráva ered, az Osztrák-Magyar Monarchiához tartozott. Itt érdemes kitérnünk arra is, hogy született egy semleges megoldás is a problémára: az atlaszokban a magyar szakaszon Dráva, a szláv és olasz szakaszon Drava, az osztrák részen pedig a Drau név szerepeljen (Touring 1991: 5-7).

A Rába folyó nevének esetében a leggyakoribb megoldás ( 8 előfordulással) a magyar Rába név átvitele volt, mégis előfordult a német alak is magyarázó betoldással: il fiume Raab (Vagnini 2015: 70) vagy anélkül: Raab (Ferrario 1933: 12, Touring 1991: 186-187). A forrásokat megfigyelve észrevehetjük, hogy az összes mü későbbi annál az időszaknál, amikor Magyarország még az Osztrák-Magyar Monarchia részét képezte, így nincsen történelmi magyarázata annak, hogy a szerzők miért a németes alakokat használták. Földrajzi elhelyezkedését illetően azonban indokolható, hiszen a kérdéses folyó Stájerországban (Ausztriában) ered.

4.2. A topográfiai szemléletből és az igazgatási hagyományokból adódó különbségek. A hegységek, dombságok, síkságok és fennsíkok esetében nagyon sok megnevezési eltérés volt megfigyelhető, hiszen a célnyelvi földrajzi kategória sokszor eltért a forrásnyelvitől. Ismeretes, hogy Olaszország és Magyarország domborzatának jellege eltér, különbözik a szemléletmód is, ezért más kategóriák szerint vannak csoportosítva a földrajzi egységek. Tipikus különbség például, hogy amit a magyarban már hegy(ség)nek tartunk, azt az olaszok még domb(ság)nak látják és nevezik. Ezekben az esetekben nagyon nehéz megtalálni a megfelelő megoldást, hiszen a szerzőnek el kell döntenie, hogy egyszerüen lefordítja-e a magyar köznevet (pl. hegység), vagy inkább figyelembe veszi az adott földrajzi egység tulajdonságait, és az olasz rendszer szerint nevezi el a helyet. Mivel nem minden szerző jut ugyanarra a döntésre, a célnyelvi ekvivalensek használata nem egységes.

4.2.1. A topográfiai szemléletből adódó különbségek. A két országnak nemcsak a közigazgatási felosztása, de a topográfiai szemlélete is rendkívül különbözö. Míg a magyarban jellemző a domb-dombság-dombvidék, hegy-hegység-hegyvidék, sík-síkságsíkvidék stb. típusú bővülés, addig ezt általában a többi nyelv nem tudja ebben a formában visszaadni. Az alábbi pontokban elsősorban az ebböl adódó különbségeket vesszük sorra.

4.2.1.1. Síkságok és mélyföldek. Az Alföld esetében rendkívül sok fordítói megoldás fordult elö; ezek tartalmazzák az Alföld tulajdonnevet, de - betoldva - különböző közneveket is: terre basse (ARE. 56), paese basso (Visintin 1947: 138), bassopiano (Balla 1937: 157), pianura (Mattei 1913: 201). Az olasz Enciclopedia Treccani szerint pianura ('síkság') vagy bassopiano ('mélyföld') a neve azoknak a földrajzi egységeknek, amelyeknek alacsony a tengerszint feletti magasságuk, nincs a területükön jelentős szintkülönbség, és általában hegységekkel, dombságokkal vannak körülvéve (Treccani bassopiano a.). A két szó definíciói tökéletesen illenek az Alföldre, és nincs jelentősége, hogy melyiket részesítjük előnyben. GÖNCZY-SZALAI Geomorfológiai fogalomgyüjteménye (2004) szerint 
mélyföldről akkor beszélünk, ha a terület magassága tengerszint alatti. A Grande Dizionario Italiano szerint viszont a mélyföld magassága 200-300 méter közötti lehet (GDI. bassopiano a.). Így tehát míg magyarul helytelen lenne az Alföldet mélyföld-nek nevezni, addig az olasz gondolkozás szerint teljesen megfelelö.

Két másik érdekes esettel is találkoztam, ahol nem a domborzati különbségekből fakad az elnevezés helytelensége/helyessége, hanem valamilyen félreértés, félreértelmezés eredményezi. Ilyen a Dunántúl nevének Pannonia megfelelője (Migliorini 1933: 27, Pullè 1934: 393). Magyarul a Pannónia a Római Birodalom egyik provinciájára utal, amely nemcsak a mai Dunántúl területén terült el, hanem a mai Ausztria, Szlovákia, Szerbia, Horvátország, Szlovénia és Bosznia-Hercegovina területén is. Így a Pannónia név használata a Dunántúl esetében nem helyes. Hasonló a helyzet a Kisalföld esetében, ami Pannonia settentrionale néven, azaz 'Észak-Pannónia'-ként fordult elő (Balla 1937: 131). Ennél a megoldásnál is ugyanazt a párhuzamot vonhatjuk a forrásnyelvi és a célnyelvi megfelelő között, mint fentebb a Dunántúl esetében. Érdekes lenne megvizsgálni, hogy a mai olasz irodalom miként említi a magyar Dunántúl és Kisalföld neveket, de e földrajzi egységek az általam vizsgált müvek közül csak a hivatkozottakban fordultak elö.

Egy másik különös eset a Duna-Tisza köze név lefordítása volt, amelyet sajátos magyar nyelvi szerkezete miatt (köze) is körülményes kifejezni bármelyik idegen nyelven. Négy forrásban is megtaláltam a Mesopotamia Ungherese nevet (Migliorini 1933: 32, Pullè 1934: 398, Baratta 1938: 68-69, Visintin 1947: 140). Ez az elnevezés az olaszban megfelelhet, hiszen a Duna és a Tisza folyók között elterülő síkságról van szó. Feltevésem szerint az elnevezés azért terjedt el, mert a szerzők lemásolták egymásról. Kutatásaim szerint az első forrás, amelyben ez az alak elöfordult, Elio Migliorinié (1933), így feltehetőleg az ő ötlete volt a metafora. Megjegyzendő, hogy az általam vizsgált forrásokban alig esik szó erről a földrajzi egységröl, így viszonylag kevés is az adat, amelyből következtetéseket lehetne levonni. További vizsgálatok tárgya lehetne annak a kérdéskörnek a feldolgozása, hogy napjainkban a (történeti, földrajzi, geológiai, néprajzi, régészeti) szakirodalomban miként hivatkoznak a kutatók erre a tájra.

4.2.1.2. Hegységek és dombságok. Ahogyan a síkság és a mélyföld esetében is láthattuk, a hegységek és a dombságok esetében is eltéréseket figyelhetünk meg a szemléletben, s így a megnevezésekben is. Vannak például ebben a körben is olyan földrajzi szakszavaink, amelyeket olasz megfelelö híján körülírással lehet visszaadni (pl. a középhegység).

A Mátra hegység esetében például előfordult az il monte Mátra (AGS. 32-33) és a la montagna della Mátra (Tagliavini 1929: 28). A monte a Grande Dizionario Italiano szerint 'egy, a tengerszint felett 600 méterrel elhelyezkedő földrajzi egység', míg a montagna átlagmagassága 600 méter feletti (GDI. monte, montagna a.). A magyar források szerint a Mátra középhegység, azaz olyan hegység, amelynek tengerszint feletti magassága kb. 500-1500 méter közé esik (ÉKsz. ${ }^{2}$ ). Igy tehát a magyar definíció szerint a Mátra az olasz montagna és monte kategóriába is besorolható.

A Bükk nevének vizsgálatakor a következő megoldásokkal találkoztam: $i$ monti di Bükk (Balla 1937: 201), la montagna del Bükk (Tagliavini 1929: 37), il massiccio del Bükk (Tamborini 1990: 9), le colline di Bükk (Migliorini 1933: 165). A Dizionario della Lingua Italiana (Sabatini-Coletti) szerint a massiccio ('hegytömb') 'olyan földrajzi egység, amely több hegységből áll, és egy különálló egységet alkot a többi hegységhez képest' (DLI. massiccio a.). Ennek a definíciónak, illetve a monte és a montagna definíciójának 
ismeretében megállapíthatjuk, hogy a Bükk esetében mind a három elnevezés helyes lehet. Az olasz collina ('domb') jelentése az olasz források szerint 'olyan domborzati egység, amelynek magassága nem több, mint 600 méter' (GDI. collina a.). Tehát a colline di Bükk elnevezés helytelen az olaszban.

Érdekességképpen tenném hozzá, hogy a Bükk a nevét az itt jellemző bükkfáról kapta, amelynek természetesen létezik olasz neve (faggio), így akár ez a fanév is állhatna egy olasz ekvivalens alapjában, azonban az általam vizsgált könyvekben nem találtam ilyen jellegü megoldást.

Nem egyszeri eset az, hogy a magyar hegységek dombságként jelennek meg az olaszban, ugyanis a Mecsek (le colline di Mecsek; Migliorini 1933: 27, Pullè 1934: 393), a Vértes (le colline di Vértes; Migliorini 1933: 27, Pullè 1934: 394), a Tokaji-hegység (le colline del Tokaj, Bucchi-Simeoni 1931: 28; colline di Tokay, Ferrario 1933: 6), a Pilis (le colline di Pilis, Migliorini 1933: 27) és a Budai-hegység (le colline di Buda; Ferrario 1933: 11, Pullè 1934: 394) esetében is ezzel az ekvivalenssel találkoztam. Feltételezhetnénk, hogy - mivel földrajztudósok voltak - Giorgio Pullè és Elio Migliorini azért választotta a collina kifejezést, mert hüek kívántak maradni az adott földrajzi egységek olasz definícióihoz, ami eltér a magyar szemléletmódtól, de mind a két szerző le colline di Mecsekként említi a Mecsek hegységet, ami, mint láthattuk, helytelen (Migliorini 1933: 27, Pullè 1934: 393). Megfigyelhetjük viszont, hogy az összes forrás, amelyben colline-ként szerepelnek a hegységeink, a harmincas évekből származik. Ebből arra következtethetünk, hogy a harmincas években valószínüleg más lehetett az elnevezési gyakorlat, mint a korábbi, illetve a későbbi években, hiszen néhány kivételtől eltekintve (le colline di Zemplén, Molfese 1989: 376) csak ezekben a forrásokban fordulnak elő ilyen formában.

Ahogy láthatjuk, nincs bevett gyakorlat arra, hogy a szerzők a magyar nevet fordítják-e (dombság vagy hegység), vagy a kiterjedés (elsősorban magasság) alapján többé-kevésbé önkényesen, esetleg valamilyen mérőszám alapján döntenek, a célnyelv tipológiai szemléletéhez igazítva az olasz nyelvi megfelelőt. A kifejezések adottak, a hegység megfelelöje a montagna, a dombság-é a colline. Ezt az elvet abban az esetben is követhetnénk, amikor számunkra is világos, hogy az adott hegység csak a nevében hegység (ilyen például a Velencei-hegység, amely csupán 352 m magas). Ilyenkor viszont a hegység név használata rendkívül félrevezető. A fenti példák alapján megállapíthatjuk, hogy ennek a problémának a megoldása a szerző egyéni ízlésétöl függ.

4.2.2. Az igazgatási hagyományokból adódó különbségek. Olaszország és Magyarország közigazgatási felosztása különbözik egymástól. Míg nálunk régebben vármegyék voltak, ma pedig megyék vannak, az itáliai rendszer sokkal bonyolultabb és összetettebb. Ezért lehet az, hogy a magyar megye szó ekvivalenseiként a következő megoldásokat találtam: comitato, contea, dipartimento, regione, provincia, distretto. A térképeken és az atlaszokban nincs feltétlenül szükség arra, hogy a megye szó megjelenjen, hiszen jelölve vannak a közigazgatási egységek határai, így legtöbbször csak a tulajdonnév jelenik meg, például: Somogy. Ha mégis megjelenik a megye megfelelője, az nem egységes, még ha ugyanazt az ekvivalenst használja is több szerző: la provincia Somogy (Balla 1937: 118), la provincia di Bács-Kiskun (Tamborini 1990: 32), il comitato di Hajdú-Bihar (D'Alto 1989: 88), il comitato Tolna (Sz. n. 1930: 29). A magyar vármegye esetében ugyanezeket a megoldásokat találtam. Kivétel ez alól a contea ekvivalens, amely a vármegyék esetében sehol sem szerepelt. 
A probléma megoldását mindenképpen a névadási gyakorlat egységesítésében látom. Ennek értelmében a megfeleltetések a következők lehetnének: vármegye - contea; nagyobb országrész, tartomány neve (pl. Erdély) - provincia; régió - regione; megye - dipartimento, comitato; járás - distretto.

5. Konklúziók. Kutatásomban is jól látszik, hogy mennyire nehéz helyzetben vannak a szerzők, fordítók, ha helyneveket kell fordítaniuk, és a célnyelvben nincsen egyértelmü, bevett megfelelöje a forrásnyelvi elnevezésnek. A magyar és az olasz nyelv között ez a probléma gyakran felbukkan. Ha mégis létezik célnyelvi alak, az - mint láthattuk - mindig történelmi okokra vezethető vissza: az adott földrajzi egység olasz szempontból is fontos volt a történelem egy bizonyos időszakában (pl. Szeged). Megfigyelhető, hogy bár egyegy magyar helynévre létezik olasz név, a szerzők nem minden esetben azt használják, hanem - az átvitel megoldását választva - a magyar nevet részesítik előnyben. Ennek az lehet a célja (például egy térkép vagy egy útikönyv esetében), hogy a Magyarországra érkező olaszok a térképeken és az útikönyvekben is ugyanazzal a névvel találkozzanak, mint amit a magyar kiírásokon, táblákon látnak, így rögtön felismerjék. További probléma azoknak a magyar karaktereknek a megjelenítése az olasz forrásokban, amelyek nem léteznek az olasz ábécében (á, $i, o, o, o, o ́, u, u, u)$. Ahogy láthattuk, jelentős eltéréseket okoznak még a két ország közötti tipológiai szemléleti különbségek és igazgatási hagyományok eltérései, illetve ezek nyelvi leképzése. A müvek nagy részében a szerzők igyekeznek hủek maradni a tárgyalt korszakhoz, viszont olyan esetek is vannak, ahol ugyanarra a földrajzi egységre több különböző elnevezést is találhatunk. Ez meglehetősen félreérthető és zavaró lehet egy nem magyar olvasó számára. Emellett olyan szerzők is vannak, akik a németes alakok átvitelét preferálják a magyar helyett.

Igen ritka tehát az egységes névhasználat: a földrajzi egység többféle néven szerepelhet a különböző szerzőknél, ráadásul olykor ugyanaz a szerző is többféle alakot használ ugyanannak a földrajzi egységnek a jelölésére. Ilyen például Giorgio Pullè könyve, amelyben a Balaton neve négyféleképpen fordul elő: il Balaton, lago Platten, il Lago Balaton, Lago Balaton (Pullè 1934: 385-386, 394-395, 403). Ez a jelenség rendkívül félrevezető lehet az olvasó számára, és nehezíti a referens identifikációját is, hiszen joggal gondolhatja, hogy a Lago Balaton és a lago Platten nem ugyanarra a tóra vonatkozik.

Érdemes lenne feltárni, hogy a vizsgált könyvek szerzői milyen nyelveket beszéltek, mik és mikoriak voltak a forrásaik, hiszen ezek a tényezők bizonyára befolyásolták névadási gyakorlatukat. Mindezekre a felvetésekre a további kutatás adhatja meg a választ.

\section{Felhasznált források}

AGS. $=$ Sz. n. 1989. Atlante geografico \& Atlante storico. Loescher Editore, Torino.

ARE. $=$ Sz. n. 1965. Atlante delle regioni d'Europa. Istituto Geografico de Agostini, Novara.

Balla, Ignazio 1937. L'Ungheria e gli ungheresi. Fratelli Treves Editori, Milano.

Baratta, Mario 1938. Grande Atlante geografico, storico, fisico, politico, economico 1-2., Istituto

Geografico di Novara, Novara.

Baratta, Mario 1954. Atlante Storico. Istituto Geografico de Novara, Novara.

Bardini, Mario 1961. Finalmente ho visitato a Russia. Gastaldi Editore, Milano.

Biagini, Antonello 2006. Storia dell'Ungheria. Bontempelli, Milano. 
Boroli, Achille - Boroli, Adolfo 1965. La Terra. Grande atlante geografico, economico, storico 1-3. Istituto Geografico de Agostini, Novara.

Brote, Eugenio 1896. La questione rumena in Transilvania ed Ungheria. Roux Frassati e C Editori, Torino.

Bucchi, Giulio - Simeoni, Alberto 1931. Trianon, Calvario d'Ungheria. Sapientia Roma, Roma.

Cucchetti, Gino 1939. L'Ungheria di fronte al problema slovacco. G. B. Palumbo Editore, Palermo.

D’Alto, Silvano 1989. La città nascosta. Mito e territorio in Ungheria. Buezoni Editore, Roma.

De Carlo, Salvatore - Molinelli, Romolo 1941. Il mondo d'oggi. Enciclopedia geografica universale. XX Secolo Edizioni, Milano.

De Magistris, Luigi Filippo 1917. Calendario Atlante de Agostini. Istituto Geografico de Agostini, Novara.

Ferrario, Carlo, Antonio 1933. Italia ed Ungheria. Alfredo Guida Editore, Napoli.

Fornaro, Pasquale 2006. Ungheria. Edizioni Unicopli, Milano.

Gemelli Careri, Francesco 1728. Giro del mondo, Tomo ottavo (in Ungheria). Venezia.

Hoduig, Armando 1915. L'Ungheria e i magiari nella guerra delle nazioni. Treves, Milano.

Imperato, F. 1914. Atlante di bandiere, insegne, distintivi dei principali stati del mondo. Hoepli, Milano.

Leoni, Leonida 1913. Testo atlante ferroviario. Istituto Geografico de Agostini, Novara-Roma.

Mattei, Franco 1913. L'Ungheria e gli ungheresi. Fratelli Bocca Editori, Torino.

Migliorini, Elio 1933. L'Ungheria. Paolo Cremonese Editore, Roma.

Molfese, Franco 1989. Ungheria - Guida all'Ungheria, SugarCo Edizioni, Milano.

Nangeroni, Giuseppe 1950. Atlante Geografico Zanichelli. Zanichelli, Bologna.

Pullè, Giorgio 1934. Svizzera - Austria - Ungheria - Cecoslovacchia - Polonia. In: Pullè, Giorgio ed., Terra e Nazioni 1-2. Casa Editrice Dottor Francesco Vallardi, Milano.

Scrimali, Antonio 1934. La revisione del trattato del Trianon. Editrice La Luce, Palermo.

Sz. n. 1930. Avete già veduto Budapest e l'Ungheria? IBUSZ, Budapest.

Tagliavini, Carlo 1929. L'Ungheria. Seconda Serie Politica-Storia-Economia. Pubblicazione dell'Istituto per l'Europa Orientale, Roma.

Tagliavini, Carlo 1940. In Ungheria. Società Nazionale Dante Alighieri, Roma.

Tamaro, Attilio 1923. La lotta delle razze nell'Europa danubiana. Zanichelli, Bologna.

Tamborini, Marco 1990. Ungheria, Touring Club Italiano, Milano.

Touring 1991 = Grande Atlante geografico e storico. UTET, Torino, 1991.

Vagnini, Alessandro 2015. Ungheria: la costruzione dell'Europa di Versailles. Carocci Editore, Roma. Visintin, Luigi 1947. Atlante geopolitico universale. Istituto Geografico De Agostini, Novara.

Visintin, Luigi 1956. Atlante mondiale. Istituto Geografico De Agostini, Novara.

\section{Hivatkozott irodalom}

CHesterman, ANDRew 2000. Memes of Translation. Benjamins Translation Library 22. John Benjamins Publishing Company, Amsterdam.

DLI. = COLETTI, FrANCESCO - SABATINI, VitTORIO, Dizionario della Lingua Italiana . Rizzoli, Milano, 2018. https://dizionari.corriere.it/dizionario italiano/

ÉKsz. ${ }^{2}=$ Magyar értelmezö kéziszótár. Főszerk. PuszTAI FERENC. 2., átdolgozott kiadás. Akadémiai Kiadó, Budapest, 2003. 
FNESz. = KISS LAJOS, Földrajzi nevek etimológiai szótára 1-2. 4., bővített és javított kiadás. Akadémiai Kiadó, Budapest, 1988.

GDI. = GABRIELLI, ALDO, Grande Dizionario Italiano. Hoepli, Milano, 2018. https://dizionari.repubblica.it/italiano.html

GÖNCZY SÁNDOR - SZALAI KATALIN 2004. Geomorfológiai fogalomgyüjtemény. Kárpátaljai Magyar Pedagógusszövetség, Beregszász.

Klaudy Kinga 2012. Bevezetés a forditás gyakorlatába. Scholastica, Budapest.

Treccani $=$ Enciclopedia Treccani. Istituto della Enciclopedia italiana fondata da Giovanni Treccani, Roma, 2018. http://www.treccani.it/enciclopedia/

Vermes Albert PÉTER 2005. Proper names in translation. A relevance-theoretic analysis. Névtani Értesitö 27: 311-314.

DOMÁNY BARBARA

ORCID: https://orcid.org/0000-0002-4964-9869

ELTE Eötvös Loránd Tudományegyetem

Bölcsészettudományi Kar

\section{BARBARA DOMÁNY, The appearance of the toponyms of the Carpathian Basin in Italian sources}

The paper examines how the toponyms of the Carpathian Basin (mostly those of Hungary) appear in $20^{\text {th }}$ - and $21^{\text {st }}$-century Italian sources, such as maps, atlases, travel guides and journey books. The author also discusses the translation strategies for proper names and shows how important historical events appear in naming practices. How the differences in the geographical features and the divergence of the administrative divisions of Hungary and Italy can create confusion in the translation of the toponyms is also shown. The author then presents how the fact that Hungary was a part of the Austro-Hungarian Monarchy influenced the practice of name giving in the period under discussion, and later. After examining 67 sources, the author prepared a dictionary containing 69 Hungarian toponyms and their Italian equivalents as used in the past and the present day. 